\title{
Effect of total leucocyte count on whole blood filterability in patients with peripheral vascular disease
}

\author{
MJ ALDERMAN, ANNE RIDGE, AA MORLEY, RG RYALL, AND JA WALSH \\ From the Departments of Haematology and Surgery, Flinders Medical Centre, Bedford Park, South \\ Australia 5042
}

SUMMARY An abnormal filterability of whole blood through micropore membranes in vitro has been reported in peripheral vascular disease and has been thought to indicate abnormal red cell deformability. Blood from 68 patients with symptomatic peripheral vascular disease of varying severity and from 32 age-matched controls without a history of peripheral vascular disease was studied by the technique of whole blood filtration. In agreement with earlier findings, whole blood filterability was significantly reduced in patients with symptoms of vascular disease, but also their total leucocyte count was significantly higher than that of the controls. Variation in leucocyte count was found to affect significantly whole blood filterability, and the abnormal filterability in peripheral vascular disease could be entirely ascribed to this factor and not to an alteration in red cell deformability. The raised leucocyte count was not due to smoking but its cause could not be explained.

Various in-vitro filtration techniques have been used to measure in-vivo red cell deformability. ${ }^{1-5}$ In an attempt to mimic conditions pertaining in vivo Reid et al. ${ }^{6}$ measured the filtration rate of anticoagulated whole blood through Nuclepore membranes with a pore size of approximately $5 \mu \mathrm{m}$. They studied a group of patients suffering from peripheral vascular disease (PVD) and found a significant difference in whole blood filterability between patients and agematched controls.

Since the technique of whole blood filtration is simple, possibly more physiological than other techniques, and reportedly able to detect abnormality in disease we studied it in some detail, both to investigate variables affecting it and to study further its value as a measure of erythrocyte deformability in PVD.

\section{Patients and methods}

All the patients in the study were referred from the vascular clinic with symptoms of intermittent claudication of varying severity. Out of 44 men (mean age 62.8) 28 were smokers, two had recently ceased smoking, and 14 were non-smokers. Out of 24 women (mean age $62 \cdot 8$ ) four were smokers, two had recently ceased smoking, and 18 were nonsmokers.

Blood was donated by 32 controls ( 22 women and 10 men), members of a senior citizens' club, aged between 55 and 86 years (mean age 67). None of them had a history of PVD, all were in good health for their age, and only three (two men and one woman) were cigarette smokers. All subjects had fasted and refrained from smoking for 10 hours before blood collection.

Venous blood was used throughout the investigation. Specimens were withdrawn with a minimum of occlusion and anticoagulated with $2 \mathrm{mg} / \mathrm{ml}$ dipotassium EDTA $\left(\mathrm{K}_{2}\right.$ EDTA). The filterability of this blood decreased slightly with time. Filtration rates were measured under standard conditions in which all blood samples were allowed to cool to room temperature $\left(21^{\circ} \mathrm{C}\right)$ before filtrations were begun and all tests were completed within 30 minutes of sampling. Anticoagulants other than EDTA were investigated but discarded. Heparin was rejected because it permitted platelet aggregation, which rapidly blocked the filter pores, and sodium citrate $(3.8 \%)$ produced a rapid loss of filterability over a 
period of five minutes, presumably owing to red cell shrinkage and loss of deformability.?

Whole blood filterability was measured by the method of Reid et al.,8 with some minor modifications. The pore diameter of the Nuclepore polycarbonate membranes (Nuclepore Corporation, Pleasanton, Ca. 94566, Batch No. 54B7A9) was nominally $5 \mu \mathrm{m}$, but since we and others ${ }^{3}$ have observed considerable variation in the pore size of different batches of membranes only those from within one batch were used. This batch was analysed by measuring pore diameters of two membranes from each of 20 boxes using a Quantimet image intensifying system (IMANCO, Melbourn, Royston, Hertfordshire, UK). The mean pore diameter was $6 \cdot 4 \mu \mathrm{m}$ (SD 0.18).

Filters were assembled in 'Pop Top' filter holders (Nuclepore) according to the manufacturer's instructions. After assembly the dead space above the membrane was filled with well-mixed blood. The barrel of a $1-\mathrm{ml}$ tuberculin syringe was then fitted into the filter holder and filled to the $1.0 \mathrm{ml}$ mark with blood. A suction pressure of $100 \mathrm{~mm}$ water was applied across the filter, a stopwatch started, and the volume of blood passing through the filter in one minute was recorded. Four filtrations were performed on each blood sample. The red cell count was measured on each filtrate, the number of cells passing the filter in one minute was calculated for each filtration, and the mean value determined. Total white cell counts (WCC) were also measured both on pre- and post-filter samples. Red and white cell counts were measured with a Coulter ZB1 counter, platelet counts with a Technicon Hemalog 8/90, and the microhaematocrit was measured with a Linson Cellocrit centrifuge.

In experiments investigating the effect of $\mathrm{WCC}$ on whole blood filterability blood from volunteer laboratory workers was taken into $\mathrm{K}_{2}$ EDTA and centrifuged at $350 \mathrm{~g}$ for five minutes. The plasma was then removed and centrifuged again for 20 minutes at $2500 \mathrm{~g}$. The erythrocytes were added back to the platelet-poor plasma at physiological concentrations (range 4.02-6.98 $\times 10^{12} / 1$; mean $\left.5.10 \times 10^{12} / 1\right)$. To portions of this reconstituted blood varying amounts of a white cell concentrate (prepared by centrifuging blood from the same volunteer) were added to give a range of values for WCC. These blood samples were then filtered by the same method as that used for the patient samples.

In experiments performed to measure the effect of haematocrit blood from healthy volunteers was collected into $\mathrm{K}_{2}$ EDTA and centrifuged at $2500 \mathrm{~g}$ for 20 minutes. After separately removing the plasma and buffy coat a total leucocyte count was performed on the concentrated red cells. Some of the buffy layer was added to autologous plasma to give a WCC identical with that of the concentrated red cells. The concentrated red cell suspension was then reconstituted with the plasma/white-cell mixture to give blood samples with varying haematocrits but with constant but physiologically subnormal concentrations of leucocytes (range 1.1-4.5 10\%/1; mean 2.9 $\times$ $\left.10^{9} / 1\right)$. After complete mixing the blood samples were filtered by the method previously described.

\section{Results}

FACTORS INFLUENCING WHOLE BLOOD FILTERABILITY IN VITRO

Total leucocyte count (WCC)

Fig. 1 shows the linear relationship between the filterability of whole blood and the logarithm of the

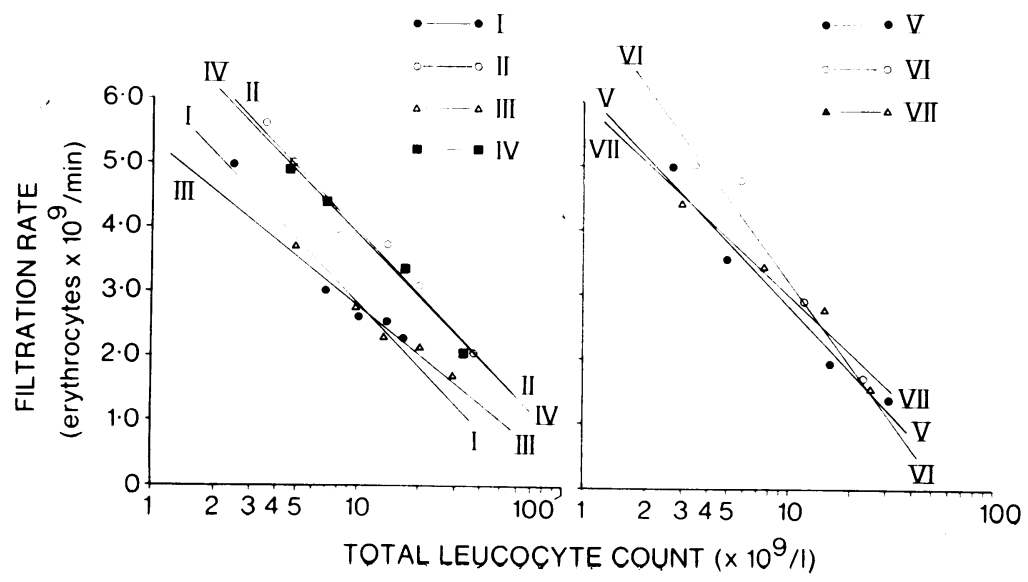

Fig. 1 Relationship between variation in WCC and whole blood filtration rate in seven different subjects. 


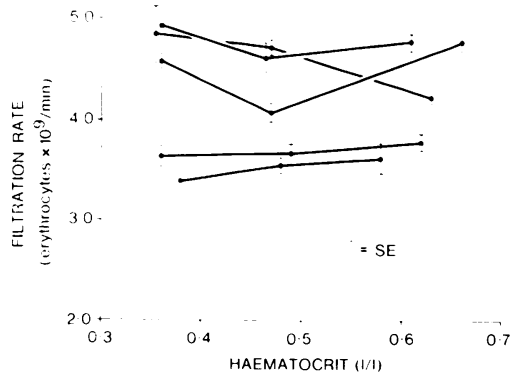

Fig. 2 Relationship between variation in haematocrit and whole blood filtration rate in five different subjects.

WCC. Seven blood samples were analysed, each adjusted to give a range of WCC. Each experimental point plotted is the mean of four observations, and the lines drawn are the calculated linear regression lines for the samples.

For each individual there was a highly significant $(P<0.01)$ relationship between the filterability and the logarithm of the WCC. For the seven as a group the mean $( \pm \mathrm{SE})$ slope of the regression line was $-3 \cdot 31 \pm 0 \cdot 23$.

In view of the close relationship between filterability and WCC it was possible to eliminate the effect of WCC by correcting the measured filterability to a standard WCC of 7500 . Thus, if F was the observed filterability, Fs the corrected filterability, and $\mathrm{c}$ a constant then

$$
\begin{aligned}
F & =-3.31 \quad \log \mathrm{WCC}+\mathrm{c} \\
\text { and Fs } & =-3.31 \quad \log 7 \cdot 5+\mathrm{c} \\
\therefore \mathrm{Fs} & =\mathrm{F}-3.31 \times \log \frac{7 \cdot 5}{\mathrm{WCC} .}
\end{aligned}
$$

\section{(2) Haematocrit}

Fig. 2 shows the results of five experiments performed to test the effect of haematocrit on whole blood filterability, each point representing the mean of four filtrations.

Haematocrits encountered in the clinical study ranged from $0 \cdot 35$ to $0 \cdot 58$. Results of the five determinations at these levels were analysed using an analysis of variance. The difference between results within this range was found not to be significant at the
Table 1 Haematological data expressed as the mean for

\begin{tabular}{|c|c|c|c|c|c|c|}
\hline & \multicolumn{2}{|c|}{ Claudicants } & \multicolumn{2}{|c|}{ Controls } & \multicolumn{2}{|l|}{$P$} \\
\hline & $\begin{array}{l}\text { Men } \\
(n=44)\end{array}$ & $\begin{array}{l}\text { Women } \\
(n=24)\end{array}$ & $\begin{array}{l}\text { Men } \\
(n=10)\end{array}$ & $\begin{array}{l}\text { Women } \\
(n=22)\end{array}$ & $\begin{array}{l}\text { Men/ } \\
\text { men }\end{array}$ & $\begin{array}{l}\text { Women/ } \\
\text { women }\end{array}$ \\
\hline $\begin{array}{l}\mathrm{Hb}(\mathrm{g} / \mathrm{dl}) \\
\operatorname{RCC}\left(\times 10^{12} / \mathrm{l}\right) \\
\operatorname{HCT}(1 / 1) \\
\text { MCV (fl) } \\
\text { Platelets }\left(\times 10^{9} / 1\right) \\
\text { TWCC }\left(\times 10^{\circ} / 1\right)\end{array}$ & $\begin{array}{l}15 \cdot 3 \\
5 \cdot 09 \\
0 \cdot 464 \\
89 \cdot 3 \\
257 \\
8 \cdot 33\end{array}$ & $\begin{array}{l}14 \cdot 2 \\
4 \cdot 79 \\
0 \cdot 437 \\
89 \cdot 0 \\
278 \\
7 \cdot 94\end{array}$ & $\begin{array}{l}15 \cdot 5 \\
4 \cdot 92 \\
0 \cdot 444 \\
90 \cdot 2 \\
231 \\
6 \cdot 62\end{array}$ & $\begin{array}{l}13 \cdot 9 \\
4 \cdot 63 \\
0 \cdot 420 \\
89 \cdot 8 \\
255 \\
6 \cdot 10\end{array}$ & $\begin{aligned} & \text { NS } \\
& \text { NS } \\
&<0.05 \\
& \text { NS } \\
& \text { NS } \\
&<0.01\end{aligned}$ & $\begin{array}{l}\text { NS } \\
\text { NS } \\
\text { NS } \\
\text { NS } \\
\text { NS } \\
<0.005\end{array}$ \\
\hline
\end{tabular}
each group. Number of patients in each group shown in parentheses

$0.05 \%$ level. Therefore no correction for haematocrit was made in the clinical study.

STUDIES IN PERIPHERAL VASCULAR DISEASE Table 1 summarises the haematological data. As expected, men had a higher haemoglobin concentration and red cell count. The most impressive difference between claudicants and controls was the higher WCC in both men and women claudicants $(\mathrm{P}<0.005)$.

When the patients were compared as a group with normal age-matched controls the claudicants had a significantly lower whole blood filterability $(\mathrm{P}<0.025)$ (Table 2). When men and women were compared separately the difference in filterability persisted: although the magnitude was similar its statistical significance was lost $(P<0.25$ men, $<0.15$ women), presumably owing to the smaller number in each group. However, when the filterability of all blood samples was corrected to a standard WCC of $7.5 \times 10^{9} / 1$ the difference between patients and controls disappeared. In fact, the mean filterability of blood from claudicants became slightly greater than that from controls.

The relative importance of PVD itself, smoking, and sex for the raised WCC in PVD patients was determined by analysis of variance. The mean WCC in patients with PVD was $8.2 \times 10^{9} / 1$ whereas in controls it was $6 \cdot 2 \times 10^{9} / 1$. This difference was highly significant: $F_{1}=13.62(P<0.001)$. The mean WCC in smokers was $8.1 \times 10^{9} / 1$ and in nonsmokers $7 \cdot 1 \times 10^{9} / 1$. This difference approached but did not reach statistical significance: $F_{1}=2 \cdot 818$

Table 2 Rheological data expressed as means $\pm S E$. Number of patients in each group shown in parentheses

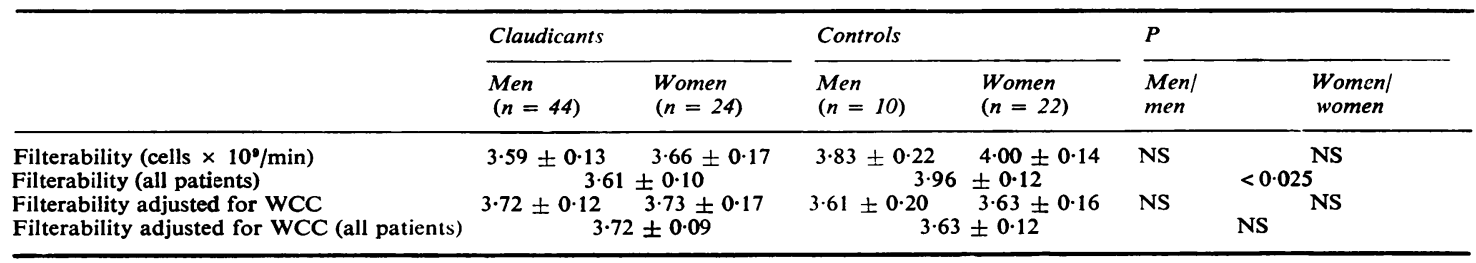


$(\mathrm{P}=<0 \cdot 10)$. Thus the main factor in the higher WCC in our patients seemed to be the presence of the disease itself, although some contribution from smoking cannot be excluded.

\section{Discussion}

Our objectives were to investigate some factors influencing whole blood filterability as measured by the method of Reid et al., ${ }^{8}$ and to use this test to study patients with peripheral vascular disease and intermittent claudication.

Reduced red cell deformability in vivo could theoretically decrease regional tissue oxygen delivery in patients with peripheral vascular disease, and it has been suggested that red cell filterability in vitro reflects in-vivo cell deformability. ${ }^{9}$ After considering methods of blood filtration through paper ${ }^{1}$ or porous membranes ${ }^{2} 38$ we chose to investigate the Nuclepore membrane filtration technique of Reid et al. ${ }^{8}$ because it is simple, uses a nearly physiological suspension medium for red cells, and because Nuclepore membranes have pores of somewhat similar diameter to that of vessels in the microcirculation. Nuclepore membranes have the practical drawback of batch-to-batch variation in pore size. The manufacturer's specified limits for pore size are $+0 \%$ to $-20 \%$ of the stated diameter, but Schmid-Schönbein et al. ${ }^{2}$ found $33 \%$ of pores in a single batch of $5-\mu \mathrm{m}$ membranes to be above or below the specified size (range 4.12-5.60 $\mu \mathrm{m}$ ). We found considerable variation between batches but acceptable variation within a single batch, and the membranes we used were all drawn from a single batch.

We have confirmed the effect of white cells on whole blood filterability noted by Heilman and Kurz. ${ }^{10}$ Leucocytes measurably impede the flow of blood through Nuclepore membranes, and our observations suggest that whole blood filterability measured by the technique of Reid et al. ${ }^{8}$ cannot be taken to indicate red cell deformability unless the result is corrected for WCC. Our results on filterability uncorrected for WCC confirmed the observation of Reid et al., ${ }^{6}$ but when they were corrected for WCC the difference between patients with PVD and controls disappeared. We conclude that the ab- $\underline{\vec{\sigma}}$ normality of whole blood filtration in PVD is not due to abnormal red cell deformability but to as़ raised WCC. Since normal leucocytes can transientlyo occlude normal small vessels and since increasedo numbers of abnormal leucocytes may occlude larger $\frac{\bar{c}}{\frac{1}{6}}$ vessels in the leucostasis syndrome, possibly the $\frac{\widetilde{\alpha}}{\alpha}$ raised WCC in patients with PVD could be a factoro in the impairment of blood flow.

We thank Dr AS Gallus for much help and advice in $\overrightarrow{\vec{\omega}}$ preparing this paper and Mrs S Phillips for typingo the manuscript.

\section{References}

1 Teital P. Le test de la filterabilité érythrocytaire (TFE) un $\vec{\nabla}$ methode simple d'étude de certains propriétés micro $\omega$ rheologiques des globules rouges. Nouv Rev Fr Hemato? 1967;7:195-214.

${ }^{2}$ Schmid-Schönbein H, Weiss J, Ludwig H. A simplet method measuring red cell deformability in models od the micro-circulation. Blut $1973 ; 26: 369-79$.

${ }^{3}$ Baar S. A convenient and reproducible filtration technique্ড for the determination of erythrocyte flexibility. $\mathrm{Br} \mathcal{\mathcal { K }}$ Haematol 1978;34:69-78.

${ }^{4}$ Forman S, Bischel M, Hochstein P. Erythrocyte deform $\vec{\infty}$ ability in uremic hemodialysed patients. Ann Intern Me $\overbrace{}^{+}$ $1973 ; 79: 841-3$.

${ }^{5}$ Mercke C, Lundh B. Erythrocyte filterability and hem® catabolism during the menstrual cycle. Ann Intern Mc $1976 ; 85: 322-4$.

${ }^{6}$ Reid HL, Dormandy JA, Barnes AJ, Lock PJ, Dormand@


lar disease. Lancet 1976;1:666-7.

${ }^{7}$ Rosenblum WI. In-vitro measurements of the effects o anticoagulants on the flow properties of blood. The res lationship of these effects to red cell shrinkage. Bloof $1968 ; 31: 234-41$.

${ }^{8}$ Reid HL, Barnes AJ, Lock PJ, Dormandy JA, Dormand TL. A simple method for measuring erythrocyte de formability. J Clin Pathol 1976;29:855-8.

"Weed RI, Lacelle PL, Merrill EW. Metabolic dependence of red cell deformability. J Clin Invest $1969 ; 48: 795-809$ ?

${ }^{10}$ Heilman L, Kurz E. Die Beschreibung einer einfachen Filtrationstechnik zur Erfassung der Erythrozyten-윽 Verformbarkeit in der Schwangerschaft. Blut 1977;35? 213-21.

Requests for reprints to: Dr MJ Alderman, Department of Haematology, Flinders Medical Centre, Bedford Park South Australia 5042. 